\title{
Optimization of the Polymerase Chain Reaction with Regard to Fidelity: Modified T7, Taq, and Vent DNA Polymerases
}

\author{
Lucy L. Ling, Phouthone Keohavong, Cremilda Dias, and \\ William G. Thilly
}

Center for Environmental Health Sciences and Division of Toxicology, Whitaker College of Health Sciences and Technology, Massachusetts Institute of

Technology, Cambridge, Massachusetts 02139

The fidelity of DNA polymerases used in the polymerase chain reaction (PCR) can be influenced by many factors in the reaction mixture. To maximize the fidelity of DNA polymerases in the PCR, PH, concentrations of deoxynucleoside triphosphates, and magnesium ion were varied. Denaturing gradient gel electrophoresis was used to separate the polymerase-induced mutants from wild-type DNA sequences. Thermolabile modified T7 DNA polymerase, thermostable Toq, and Vent DNA polymerases were studied. Fidelity of all three DNA polymerases was sensitive to concentrations of deoxynucleoside triphosphates, magnesium ion, and pH. Within conditions that permitted efficient amplification, optimization with regard to these three factors yielded an average error rate in error/base pair incorporated of $7.2 \times 10^{-5}$ for $\operatorname{Taq}, 4.5 \times 10^{-5}$ for Vent, and $4.4 \times 10^{-5}$ for modified T7 (Sequenase) DNA polymerases.
D amplification by the polymerase chain reaction (PCR) ${ }^{(1-3)}$ can be accomplished by DNA polymerases from many sources. ${ }^{(1,2,4)}$ Specific DNA polymerases have been reported to amplify with different efficiencies (i.e., yield of sequence amplification per cycle) and fidelities (frequency of polymerase-induced errors), with the kind and rate of error depending on the specific DNA polymerase and PCR conditions. ${ }^{(4-9)}$ Each error, once initiated, is amplified along with the original wild-type sequences, increasing the fraction of polymerase-induced mutant sequences linearly with the number of amplification cycles. Under low-fidelity conditions, this mutant fraction can become significant: $40 \%$ of the amplification products are mutant when a 200-bp fragment is amplified one million-fold by a DNA polymerase with an error rate of $10^{-4},(4)$ such as Klenow fragment. ${ }^{(10)}$ For some purposes such as sequencing a wild-type gene, the polymeraseinduced mutations are generally distributed over the sequence of interest so that an accurate consensus sequence is usually obtained. ${ }^{(11,12)}$ For studies of mutants within wild-type populations, it is vital that the polymerase-induced mutant sequences do not mask the preexisting mutant sequences. $(11,13,14)$

Due to its thermostability, Taq DNA polymerase has been the most widely used DNA polymerase. It does* not have to be added every cycle, as was necessary for the thermolabile
Klenow fragment referred to in the original descriptions of DNA amplification. $(1,3,10)$ However, the fidelity of Taq has been reported to be $2 \times 10^{-4}$ error/bp per duplication, ${ }^{(4,7-10)}$ which renders it unsuitable for studies requiring both low noise and high amplification. Studies requiring a higher fidelity of amplification have used DNA polymerases such as modified T7 DNA polymerase (Sequenase) or T4 DNA polymerase, $(4,13,14)$ which permitted amplification with error rates of about $3.4 \times 10^{-5}$ and $0.3 \times 10^{-5}$ error/bp per duplication, respectively. ${ }^{(4)}$ However, both T4 and modified T7 DNA polymerases are thermolabile.

Recently, a new thermostable DNA polymerase called Vent DNA polymerase was isolated and made commercially available in a cloned form by New England Biolabs (Beverly, MA). Vent was reported to have a $3^{\prime} \rightarrow 5^{\prime}$ proofreading exonuclease. ${ }^{(15)}$ Our laboratory has been screening all available thermostable polymerases and has found that this new thermostable DNA polymerase, under conditions described for primer extension, permitted amplification with a useful degree of fidelity. Reaction conditions such as $\mathrm{pH}$, concentrations of dNTP, and magnesium ion can greatly affect the fidelity of DNA polymerases. $(5,7,9,16-20)$ Eckert and Kunkel used the M13mp2 fidelity assay and found that conditions of low $\mathrm{pH}$ with low and equimolar concentrations of dNTP to $\mathrm{Mg}^{2+}$ increased the fidelity of Taq. ${ }^{(7,9)}$ We have ex- 
tended their observations using denaturing gradient gel electrophoresis (DGGE) to separate and enumerate all polymerase-induced mutant sequences from the correctly amplified sequences. To maximize the fidelity of Taq, Vent, and Sequenase, varied concentrations of dNTPs, $\mathrm{pH}$, and magnesium were tested iteratively, and the optimal conditions with regard to these variables have been defined. We have confirmed the finding of Eckert and Kunkel ${ }^{(7,9)}$ and defined conditions in which the Taq polymerase operates with a threefold improvement in fidelity during amplification in PCR relative to the most widely used reaction conditions. ${ }^{(4)}$ More importantly, we find that the thermostable Vent polymerase under optimal conditions yielded a PCR amplification with both high fidelity and high efficiency which should be of general use to researchers using PCR.

\section{MATERIALS AND METHODS}

\section{Materials}

Taq polymerase was obtained from Perkin Elmer Cetus (Norwalk, CT). Vent polymerase, purified from Thermococcus litoralis, and its recombinant form cloned in Escherichia coli (designated Rec-Vent in this paper) were obtained from New England Biolabs (Beverly, MA). Sequenase (modified T7 DNA polymerase) was obtained from United States Biochemicals (Cleveland, $\mathrm{OH}$ ). 2' -deoxynucleoside $5^{\prime}$-triphosphates (dNTPs) were obtained as $100 \mathrm{~mm}$ solution from Pharmacia (Piscataway, NJ). Primer P1, $5^{\prime}$-CATATATTAAATATACTCAC-3'; primer P2, 5'-TCCTGATTTTATTTCTGTA- $3^{\prime}$; and primer P4, 5' -GACTGAACGTCTTGCTCGAG-3' were obtained from Synthetic Genetics (San Diego, CA). [ $\gamma^{32}$ P]ATP $(6000 \mathrm{Ci} / \mathrm{mmole})$ was from New England Nuclear (Boston, MA) and T4 poly nucleotide kinase was from New England Biolabs (Beverly, MA). The reagents in the $5^{\prime}$ DNA terminus labeling system were from Bethesda Research Lab (Gaithersburg, MD).

\section{Procedure}

The stock of DNA template for PCR was obtained by amplification from human genomic DNA, followed by purification with denaturing gradient gel to ensure a homogeneous population of the desired fragment of human HPRT exon 3 and flanking intron 2 . This template was amplified from $10^{5}$ copies to about $10^{12}$ copies and polyacrylamide gel purified. An aliquot $\left(10^{10}\right.$ copies) was further amplified 100-fold, under identical conditions with primer $\mathrm{P} 4$ end-labeled by $\mathrm{T} 4$ polynucleotide kinase. ${ }^{(13)}$ The number of DNA copies generated was measured at different cycles to permit calculation of efficiency. Conditions that maintained exponential increases in DNA per cycle were used throughout this work. The ${ }^{32}$ P-end-labeled DNA of the correct size was then purified from polyacrylamide gel, boiled, and reannealed so that each strand of any PCR-generated mutant homoduplexes could be hybridized to the complementary strand of the excess wild-type products to form heteroduplexes. These heteroduplexes were then separated from the wild-type homoduplexes by denaturing gradient gel electrophoresis. For each PCR condition, the total heteroduplex and the correctly amplified homoduplex fractions were measured for the calculation of fidelity in error/base pair incorporated per duplication.

\section{PCR Procedure}

$\mathrm{pH}, \mathrm{dNTP}$, and $\mathrm{Mg}^{2+}$ concentrations were experimental variables. $\mathrm{MgSO}_{4}$ was used for Taq and Vent, while $\mathrm{MgCl}_{2}$ was used for Sequenase. For Vent and Taq, the PCR reaction mixture was $10 \mathrm{mM} \mathrm{KCl}, 10 \mathrm{~mm}$ $\left(\mathrm{NH}_{4}\right)_{2} \mathrm{SO}_{4}, 0.1 \%$ Triton X-100, 0.1 $\mu \mathrm{g} / \mu \mathrm{l}$ BSA, $1 \mu \mathrm{M}$ each primer and 20 $\mathrm{mM}$ Tris buffer. Four units of enzyme were added for every $100 \mu \mathrm{l}$ of reaction volume, with 3 more units of Taq polymerase added after 30 cycles. The amplification cycle consisted of $94^{\circ} \mathrm{C}$ for $1 \mathrm{~min}, 53^{\circ} \mathrm{C}$ for $2 \mathrm{~min}$, and $70^{\circ} \mathrm{C}$ for $2 \mathrm{~min}$. For Sequenase, the reaction mixture was $3 \mu \mathrm{M}$ each primer, and 10 $\mathrm{mm}$ Tris buffer. The amplification cycle consisted of boiling for $1 \mathrm{~min}$, cooling down to $37^{\circ} \mathrm{C}$ ( 1 minute), adding 1 unit $(1 \mu l)$ of Sequenase, and incubation at $37^{\circ} \mathrm{C}$ for $2 \mathrm{~min} .{ }^{(4)}$

\section{Efficiency}

To determine the efficiency of amplification at the exponential phase of DNA synthesis, a $5-\mu l$ aliquot of the
PCR reaction mixture was removed and electrophoresed on $6 \%$ polyacrylamide gel together with a series of authentic standards whose numbers of molecules are known. The gel was stained with ethidium bromide and the PCR products of the correct size were measured by comparing the yield of the ultraviolet-induced fluorescence emitted by the ethidium bromide molecules intercalated into the DNA of the samples of DNA of the standard. The error of this method of quantitation is about twofold. However, this would affect the efficiency only slightly. For instance, a calculated efficiency of $70 \%$ due to $10^{7}$-fold amplification after 30 PCR cycles, would be $75 \%$ if the DNA was actually twice as much. The efficiency of amplification was calculated from the formula:

$$
\frac{\text { Final DNA copy number }}{\text { Initial DNA copy number }}
$$

where $Y$ is the efficiency per cycle and $n$ is the number of PCR cycles under conditions of exponential amplification. ${ }^{(1,2,14)}$

\section{Denaturing Gradient Gel Electrophoresis (DGGE)}

To separate DNA duplexes containing only homologous wild-type sequences (WT homoduplexes) from the mutant/ wild-type heteroduplexes, denaturing gradient gel electrophoresis was employed. ${ }^{(4)}$ DNA was dissolved in a $30-\mu$ l solution of $400 \mathrm{~mm} \mathrm{NaCl}, 10 \mathrm{~mm}$ Tris buffer at $\mathrm{pH} 7.5,2 \mathrm{~mm}$ EDTA, boiled for $5 \mathrm{~min}$, and reannealed for 5 hr at $65^{\circ} \mathrm{C}$. The DNA was ethanol precipitated and separated on a denaturing gradient gel. The gel consists of a $12.5 \%$ polyacrylamide gel (acrylamide/bis-acrylamide $=37.5: 1$ ), containing a linearly increasing gradient of denaturant, parallel to the direction of electrophoresis, of $19-29 \%$ (vol/vol) where $100 \%$ denaturant is $7 \mathrm{M}$ urea $/ 40 \%$ formamide. ${ }^{(21)}$ The gel was run for $15 \mathrm{hr}$ at 150 volts while submerged in TAE buffer $(40 \mathrm{mM}$ Tris/20 $\mathrm{mM}$ acetic acid/2 mM EDTA, pH 8.3) at $60^{\circ} \mathrm{C}$, dried, autoradiographed, and recorded on a phospholmager screen (Molecular Dynamics, Sunnyvale, CA).

\section{Determination of Fidelity}

Fidelity of amplification was deter- 
mined by analyzing the denaturing gradient gel exposed to the phosphoImager screen. The amount of excitation from the radioactive bands in the heteroduplex region (from the origin of the gel to the WT homoduplex band) and the band of WT homoduplex were measured. The background noise, such as nonspecific DNA binding in the gel, was measured from control lanes loaded with only DGGE purified wild-type DNA homoduplex sequences that had been subjected to the identical treatment of boiling, reannealing, and ethanol precipitation. The background control samples were run on the same denaturing gradient gels as the experimental samples. The heteroduplex fraction $(\mathrm{HeF})$ due to polymerase amplification was calculated as: $\mathrm{HeF}=$ (Total heteroduplex counts - background heteroduplex counts)/total counts.

The fidelity was calculated ${ }^{(4)}$ as:

$$
f=\frac{\mathrm{HeF}}{b d}
$$

where $f$ is the error rate (errors/base pair incorporated.duplication); $\mathrm{HeF}$ is heteroduplex fraction; $b$ is the length of the single-strand low melting domain in which mutants can be detected (104 bp); and $d$ is the number of DNA duplications (30).

\section{RESULTS}

Table 1 shows the values of $\mathrm{pH}$, dNTPs, and magnesium with their corresponding efficiencies and fidelities that were observed in the studies with Sequenase, Taq, and Vent. Table 1A shows the efficiencies and error rates using conditions commonly used in PCR for Taq and Sequenase, ${ }^{(4)}$ or in the case of Vent, those suggested by the supplier to be successful in primer extension. Table 1B shows the improvement brought about by the optimization effort.

Figure 1 is an autoradiogram of a denaturing gradient gel comparing the polymerization-induced mutations by Sequenase, Taq, and Vent. The band of wild-type homoduplex indicated by an arrow in the figure has been confirmed by sequencing. The positions of the mutant/WT type heteroduplexes of Vent are very similar to Taq, with a few exceptions. As conditions were adjusted for the improvement of fidelity, the positions of these heteroduplexes remained the same with changes only in their intensity relative to the WT homoduplex. The specific Taq and Sequenase point mutations corresponding to these bands have been previously reported. ${ }^{(4)}$

Optimization began with the conditions of Table $1 \mathrm{~A}$ and iteratively examined the effects of dNTP concentration, $\mathrm{pH}$, and then magnesium ion concentration. The effects of dNTP concentration on fidelity are shown in Figure 2. In a first round of experiments, the dNTP concentrations that permitted each polymerase efficiency to exceed $35 \%$ were defined. Within this range, Taq displayed some improvement in fidelity by either increasing or decreasing dNTP concentrations. The fidelity of Vent was somewhat improved by increasing dNTP as was that of Sequenase. Within the ranges

TABLE 1 Summary of the PCR Conditions

\begin{tabular}{lccccc}
\hline $\begin{array}{l}\text { DNA } \\
\text { polymerase }\end{array}$ & $\begin{array}{c}\mathrm{dNTP} \\
(\mathrm{mM})\end{array}$ & $\mathrm{pH}$ & $\begin{array}{c}\mathrm{Mg} \\
(\mathrm{mM})\end{array}$ & $\begin{array}{c}\text { Efficiency } \\
(\%)\end{array}$ & $\begin{array}{c}\text { Error rate } \\
\text { (error/bp } \\
\text { incorporated) }\end{array}$ \\
\hline
\end{tabular}

A. Initial conditions

\begin{tabular}{lccccc} 
Sequenase & 2.55 & 8.0 & 5 & 90 & $5.4 \times 10^{-5}$ \\
Taq & 0.2 & 8.8 & 2 & 70 & $2.0 \times 10^{-4}$ \\
Vent & 0.2 & 8.8 & 2 & 70 & $6.6 \times 10^{-5}$ \\
B. Improved conditions & & & & & \\
Sequenase & 3.5 & 8.0 & 2.5 & 90 & $4.4 \times 10^{-5}$ \\
Taq & $0.5-1.5$ & 8.0 & 5 & 36 & $7.2 \times 10^{-5}$ \\
Vent (and Rec-Vent) & $0.5-1.5$ & 8.5 & 7.5 & 70 & $4.5 \times 10^{-5}$ \\
\hline
\end{tabular}

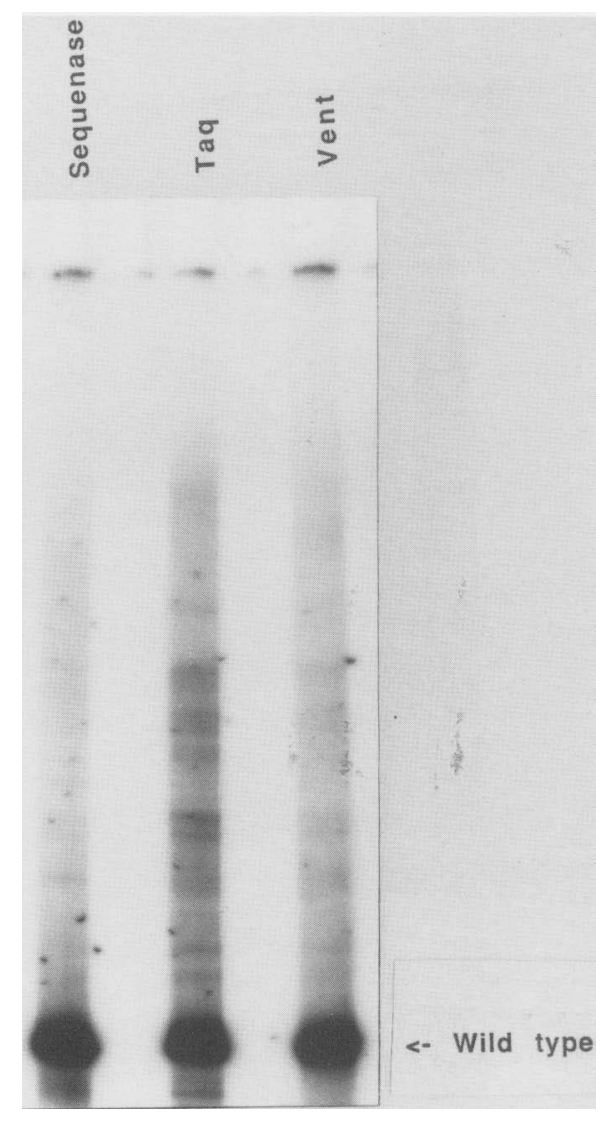

FICURE 1 Analysis by DGGE of the PCR products after $10^{9}$-fold amplification by Sequenase, Taq, and Vent DNA polymerases. The arrow points to the position where correctly amplified wild-type homoduplex focus.

shown on Figure 2, efficiencies were invariant for all polymerases, $\sim 90 \%$ for Sequenase, $\sim 70 \%$ for $\mathrm{Taq}$ and Vent. Based on these observations, $0.05 \mathrm{~mm}$, $0.5 \mathrm{~mm}$, and $3.5 \mathrm{~mm} \mathrm{dNTP}$ for Taq, Vent, and Sequenase, respectively, were used in the next stage, study of pH effects.

The efficiencies of Vent and Sequenase were relatively invariant in the $\mathrm{pH}$ range of $7-9$, but the efficiency of Taq decreased markedly below $\mathrm{pH} 8$. As shown in Figure 3, within these ranges, Taq showed an improved fidelity when the $\mathrm{pH}$ was reduced to 8 . Vent showed no change in fidelity from $\mathrm{pH} 8$ to 9 , but fidelity decreased at $\mathrm{pH}$ 7. The fidelity of Sequenase was invariant over the $\mathrm{pH}$ range of 7 to 9 . Based on these observations, $\mathrm{pH} 8.0$ was used for all three polymerases for the next step of the optimization procedure. 


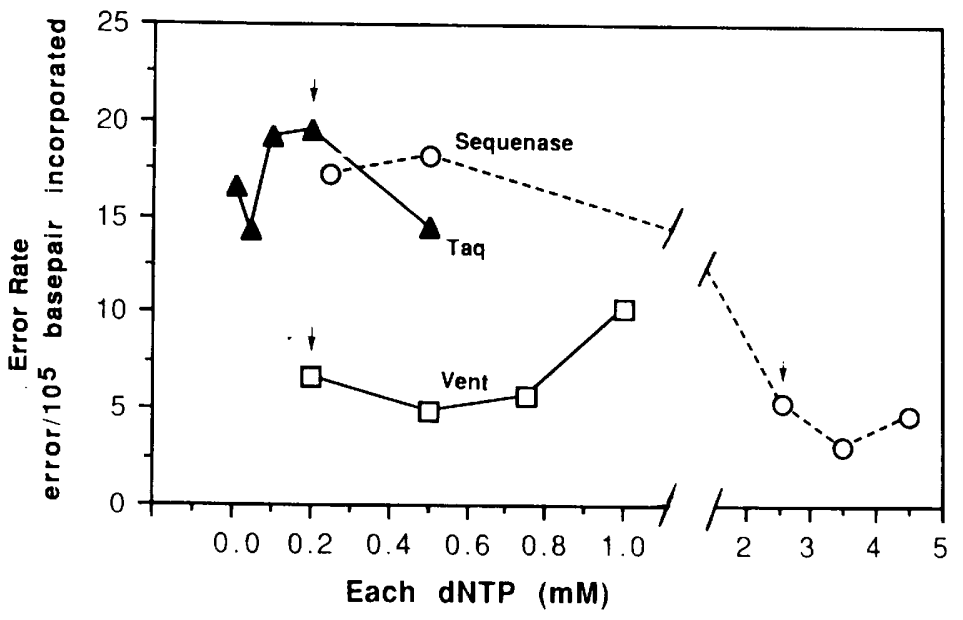

FIGURE 2 Fidelity of three DNA polymerases as a function of equimolar dNTP concentrations: ( $\mathbf{\Lambda}) \mathrm{Taq}\left(\mathrm{pH} \mathrm{8.8,2} \mathrm{mM} \mathrm{MgSO}_{4}\right.$ ), (口)Vent ( $\mathrm{pH} \mathrm{8.8,2} \mathrm{mM} \mathrm{MgSO}_{4}$ ), and (O) Sequenase ( $\mathrm{pH}$ $8.0,5 \mathrm{mM} \mathrm{MgCl} 2$ ). The efficiency was $\sim 90 \%$ for Sequenase, $-70 \%$ for Taq, and $70 \%$ for Vent, for all dNTP concentrations shown. The arrows indicate the initial concentration of dNTP.
The next factor studied was the concentration of magnesium ion. Two separate batches of Taq (Perkin Elmer Cetus) were used. One batch of Taq showed acceptable amplification $(-35 \%)$ only from 5 to $10 \mathrm{mM} \mathrm{Mg}$. As shown in Figure 4, with the magnesium concentrations that permitted acceptably efficient amplification, the fidelity of $\mathrm{Taq}$ was improved both by increasing $\mathrm{MgSO}_{4}$ to $10 \mathrm{~mm}$ or decreasing it to $0.5 \mathrm{~mm}$. Vent polymerase and its bacterially produced cloned version, Rec-Vent, were found to have similar efficiency and fidelity. Their efficiencies were insensitive to $\mathrm{MgSO}_{4}$ concentrations over the range studied, but below $2 \mathrm{mM} \mathrm{MgSO}_{4}$, the fidelity of Vent and Rec-Vent DNA polymerase decreased drastically. A small but useful improvement in Sequenase fidelity occurred when $\mathrm{MgCl}_{2}$ was decreased from $5 \mathrm{~mm}$ (Table $1 \mathrm{~A}$ ) to $2.5 \mathrm{~mm}$.

At this point conditions had been defined which yielded fidelities about $4.5 \times 10^{-5}$ for both Vent and Sequenase and as low as about $1.2 \times 10^{-4}$ for Taq polymerase, each representing improvement of fidelity over that obtained using the original conditions of Table $1 \mathrm{~A}$.

To test for covariance of effects on fidelity among the variables studied, the lowest error rate conditions from Figure 4 were then probed in reverse order with regard to the effects of $\mathrm{pH}$ and then dNTP using the two thermostable polymerases, Vent (Rec-Vent) and Taq polymerases. As may be seen by comparing Figure 5 with Figure 3, the fidelity of $\mathrm{Taq}$ as a function of $\mathrm{pH}$ was not changed by the alterations in dNTP or $\mathrm{MgSO}_{4}$ concentrations. The best fidelity of Taq was still obtained at pH 8 and efficiency dropped off below pH 8. However, the shift in dNTP and $\mathrm{MgSO}_{4}$ concentrations did eliminate the increased error rate of Vent polymerase observed at $\mathrm{pH} 7$ in Figure 3. Now a difference between native Vent and recombinant Vent polymerase was found: The efficiency of RecVent dropped precipitously below $\mathrm{pH}$ 7.5 .

Figure 6 shows the fidelity of Taq, Vent, and Rec-Vent polymerases as
dNTP concentrations were varied at the $\mathrm{pH}$ and $\mathrm{MgSO}_{4}$ concentrations that optimized fidelity. As seen by comparito amplify at dNTP concentrations above $0.5 \mathrm{~mm}$, albeit with low efficiency $(-36 \%)$. Remarkably, at $\mathrm{pH} 8$ and $5 \mathrm{mM} \mathrm{MgSO}_{4}$, the error rate of Taq dropped toward that seen previously for Vent and Sequenase, reaching a maximum fidelity at or above $0.5 \mathrm{~mm}$ dNTP. This effect was not found with the first round of optimizations (Figs. 2,3 , and 4), and emphasized the practical importance of reexamining the effect of the first two factors, namely $\mathrm{pH}$ and dNTP (Figs. 5 and 6).

The fidelity of both Vent and RecVent was relatively invariant with dNTP concentration (Fig. 6), but once again a difference between Vent and Rec-Vent preparations was found in that only Vent showed efficient amplification below $0.5 \mathrm{~mm}$ dNTP. Because only Rec-Vent will be commercially available, except upon special request from the manufacturer, the Rec-Vent results should be noted in standard PCR applications.

\section{DISCUSSION}

The error frequency of different DNA polymerases has been measured by a variety of assays and ranged from $10^{-4}$ to $10^{-7}$ error/base pair incorporated. ${ }^{(4-7)}$ In this study, a combination of PCR and DGGE provides a sensitive and reliable assay to measure the wide son with Figure 2, Taq was now found

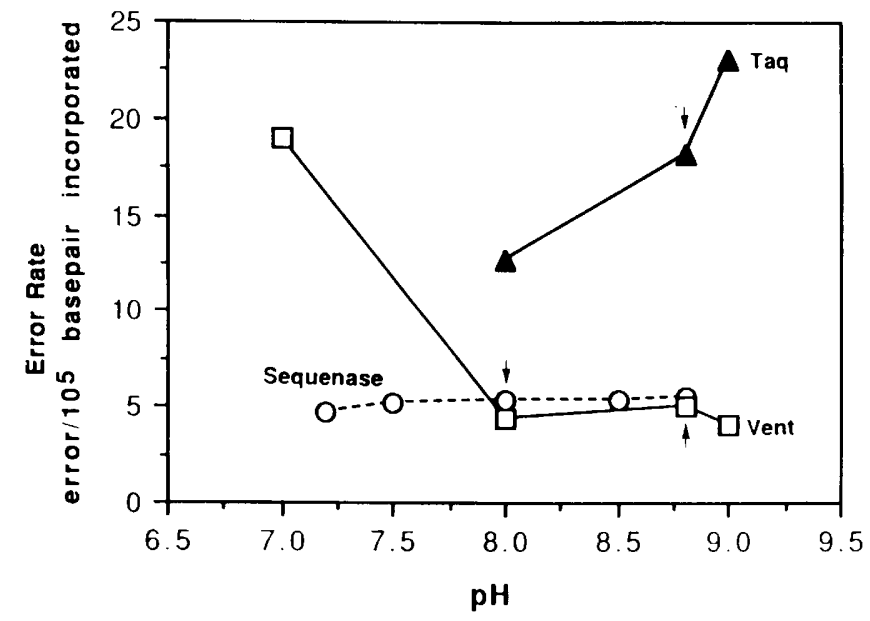

FIGURE 3 Fidelity of Sequenase, Taq, and Vent DNA polymerases as a function of $\mathrm{pH}:(\mathbf{\Lambda}) \mathrm{Taq}$ (0.05 mM each dNTP, $2 \mathrm{mM} \mathrm{MgSO}$ ), ( $\square$ )Vent $(0.5 \mathrm{mM}$ each dNTP, $2 \mathrm{mM} \mathrm{MgSO}$ ), (O) Sequenase $(3.5 \mathrm{mM}$ each dNTP, $5 \mathrm{mM} \mathrm{MgCl} 2$ ). The efficiency was $\sim 90 \%$ for Sequenase, $\sim 70 \%$ for Taq, and Vent, except for Vent at $\mathrm{pH} 9$ where it was $\sim 45 \%$. The arrows indicate the initial $\mathrm{pH}$. 


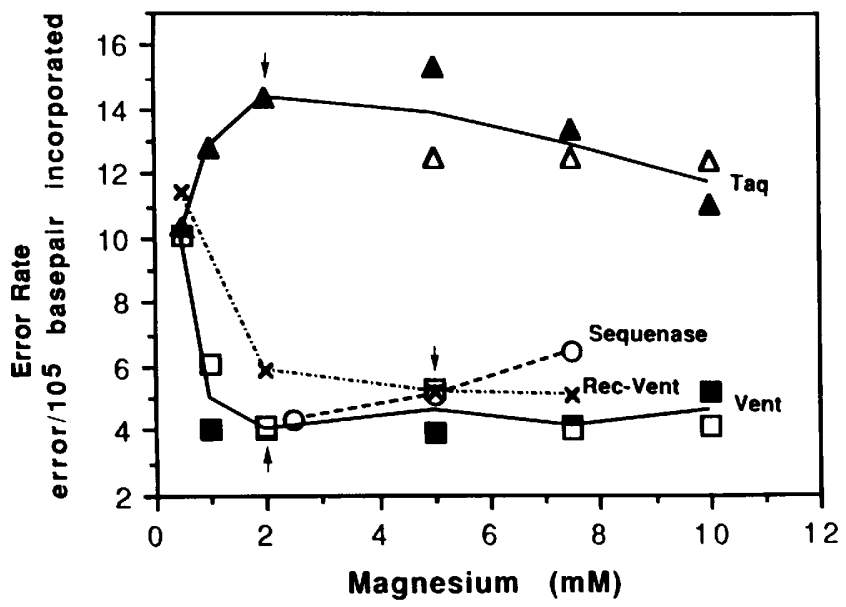

FIGURE 4 Fidelity of Sequenase, Taq, Vent, and Rec-Vent as a function of $\mathrm{Mg}^{2+}$ concentrations: $(\Delta \boldsymbol{\Delta})$ Taq $(0.05 \mathrm{mM}$ each dNTF), $(\mathbf{\square})$ Vent, $(\boldsymbol{x})$ Rec-Vent (both $0.5 \mathrm{mM}$ each dNTP), and (O)Sequenase (3.5 mM each dNTP). All reactions were at $\mathrm{pH} 8.0$, using $\mathrm{MgCl}_{2}$ for Sequenase and $\mathrm{MgSO}_{4}$ for Taq, Vent, and Rec-Vent. The efficiency was $90 \%$ for Sequenase, $-70 \%$ for $\mathrm{Taq}$ Lot $3813(\Delta)$, except at $\leq 1 \mathrm{mM} \mathrm{Mg}{ }^{2+}(36 \%), 40-63 \%$ for Taq Lot $3964(\Delta)$, and $-70 \%$ for RecVent and Vent, except at $0.5 \mathrm{mM} \mathrm{Mg}{ }^{2+}(60 \%)$. The arrows indicate the initial $\mathrm{Mg}^{2+}$ concentration.

range of fidelity of different DNA polymerases over a variety of sequence contexts in the 104-bp target studied. ${ }^{(4)}$ In its present form, error rates as low as $5 \times 10^{-6}$ errors/base pair incorporated can be measured if care is taken to begin with a sufficiently large number of denaturing gradient gel-purified templates to eliminate jackpot effects. Another advantage is that DGGE provides a fast and accurate way to measure polymerase-induced mutants in virtually any sequence of interest to the investigators. All base-pair substitutions, small additions, and deletions are detected. The nature of the sequence changes can be determined by isolating and sequencing these DNA fragments. $(4,13,21)$ However, if such information is not required, relative changes in the nature of polymeraseinduced errors can be inferred from the pattern on the denaturing gradient gel alone.

The fidelity of DNA synthesis depends on the ability of DNA polymerases to discriminate against an incorrect nucleotide being ligated onto a primer-template, to extend from the mispair, and to correct the mispair by $3^{\prime} \rightarrow 5^{\prime}$ exonucleolytic reversal of polymerization. This last ability is possible only for DNA polymerases with active $3^{\prime} \rightarrow 5^{\prime}$ proofreading exonuclease. Among the three enzymes studied here, Vent is the only one known to have an active $3^{\prime} \rightarrow 5^{\prime}$ exonuclease activity. However, its fidelity was matched by Sequenase and was 1.6fold better than Taq polymerase, both of which are reported to be devoid of exonuclease activity. $(8,22)$

The fidelity of all three enzymes, Sequenase, Taq, and Vent, was shown to be sensitive to changes in $\mathrm{pH}$, concentrations of $\mathrm{dNTP}$, and $\mathrm{Mg}^{2+}$ ions. The fidelities of $T a q$ and Sequenase were shown to have a different dependence on dNTP concentration than Vent. Previous studies of Taq had concluded that its fidelity is good at low equimolar concentration of total dNTP to $\mathrm{Mg}^{2+}$ concentration and that, in general, it is improved by lowering dNTP concentration, even in excess of $\mathrm{Mg}^{2+} .(7,9)$ Our results confirm these reports but also show that for both Taq and Sequenase, in conditions where the $\mathrm{Mg}^{2+}$ concentration is high and the total dNTP concentration is less than that of magnesium, fidelity is optimal at higher dNTP concentration. However, the fidelity of Vent, though invariant over a wide range of dNTP concentration, slightly decreased at high dNTP concentration. This may be due to diminished proofreading ability by high dNTP concentrations that has been observed in many DNA polymerases with $3^{\prime} \rightarrow 5^{\prime}$ exonuclease activity such as E. coli Pol I and T4 polymerase. ${ }^{(6,17,23,24)}$ High concentrations of dNTP are postulated to increase the rate of polymerization of the next correct nucleotide following the mispair, and thus decrease the probability of excision by the exonuclease. $(23,25)$

The effect of $\mathrm{pH}$ again showed no common trend on the fidelity of the three DNA polymerases tested. There was only a slight effect on the fidelity of Sequenase. The fidelity of Vent decreased at low $\mathrm{pH}$ only in conditions of low equimolar concentrations of dNTP to $\mathrm{Mg}^{2+}$, whereas the fidelity of Taq progressively decreased as $\mathrm{pH}$ was raised. This supports the results of previous studies on $\mathrm{Taq},{ }^{(7,9)}$ that at all $\mathrm{Mg}^{2+}$ and dNTP concentrations, the fidelity of Taq can be improved by

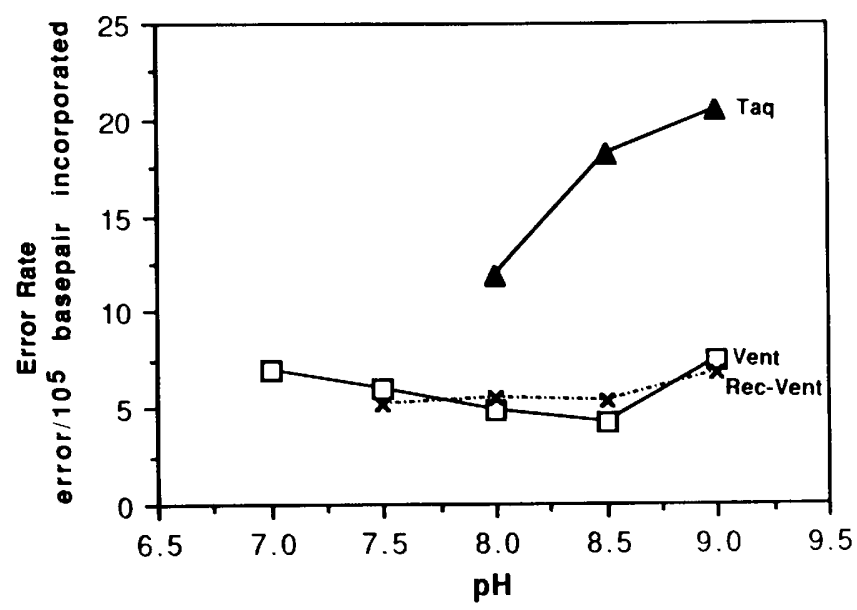

FIGURE 5 Fidelity of $T a q$, Vent, and Rec-Vent as a function of $\mathrm{pH}:(\boldsymbol{\Delta}) \mathrm{Taq}(0.05 \mathrm{mM}$ each dNTP, $5 \mathrm{mM} \mathrm{MgSO}_{4}$ ), ( $\square$ )Vent and $(\boldsymbol{x})$ Rec-Vent (both $0.5 \mathrm{mM}$ each dNTP, $7.5 \mathrm{mM} \mathrm{MgSO} 4$ ). The efficiency was $\sim 40 \%$ for Taq, $-70 \%$ for Vent, and Rec-Vent ( $57 \%$ at $\mathrm{pH} 9$ ). 


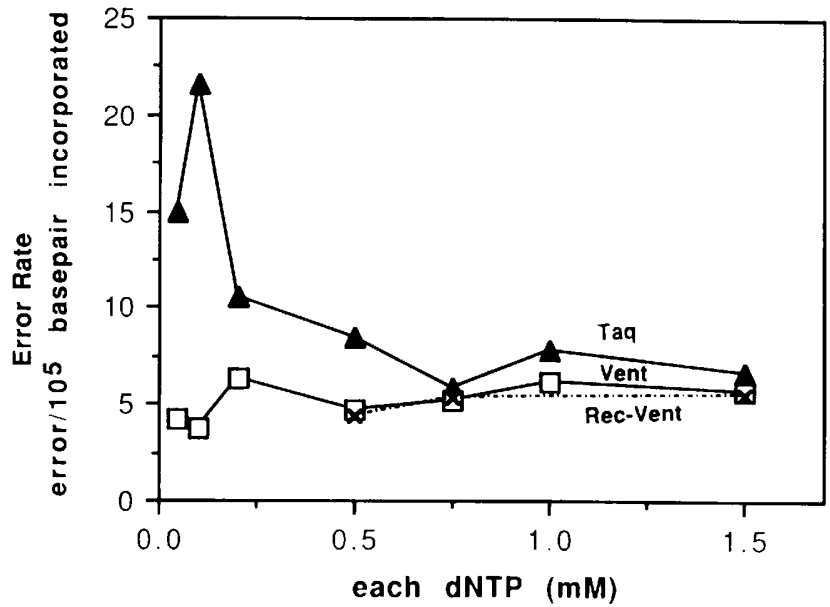

FIGURE 6 Fidelity of Taq, Vent, and Rec-Vent as a function of dNTP concentrations: $\boldsymbol{\Delta}) T_{\text {al }}$ (5 $\mathrm{mM} \mathrm{MgSO}_{4}, \mathrm{pH} \mathrm{8.0),( \square )Vent,} \mathrm{and(} \boldsymbol{x}$ )Rec-Vent (both $7.5 \mathrm{mM} \mathrm{MgSO} 4, \mathrm{pH} 8.5$ ). The efficiency was $34-38 \%$ for Taq, except at 0.5 and $1.5 \mathrm{mM}$ dNTP $(-59 \%)$, and $-70 \%$ for lent and Rec-Vent.

lowering the $\mathrm{pH} . \mathrm{Mg}^{2+}$ is used in this study as the activating divalent metal ion for DNA polymerization. It is considered a physiological activator because it is found in cells. ${ }^{(5)}$ Depending on its concentration, $\mathrm{Mg}^{2+}$ has been shown to increase or decrease polymerase fidelity. $(7,9,18,19)$ Fidelity has been shown to decrease by increasing the concentration of free $\mathrm{Mg}^{2+} \cdot(7,9)$ Indeed, the fidelities of Sequenase and Taq were very slightly decreased by high concentrations of $\mathrm{Mg}^{2+}$. The high fidelity of Vent was mainly invariant and decreased only at very low $\mathrm{Mg}^{2+}$ concentration. Other studies on DNA polymerases with $3^{\prime} \rightarrow 5^{\prime}$ exonuclease activity such as $E$. coli Pol I have similarly noted that there was no effect of $\mathrm{Mg}^{2+}$ concentration on their fidelity, ${ }^{(18)}$ except at inhibiting concentration. (19)

As adjustments in the PCR conditions were made, the intensities of all of the heteroduplexes relative to the WT homoduplex changed. However, there was no observable change in the bands of the heteroduplexes in the denaturing gradient gel. This indicates that hotspots for polymerase-induced errors were similar regardless of changes in the PCR conditions employed. The specific polymeraseinduced mutants of Sequenase and Taq have been previously reported. ${ }^{(4)}$ The positions of the heteroduplexes in the denaturing gradient gel are very similar between Taq and Vent, with a few exceptions. These bands have been isola- ted and are being sequenced.

The fidelity of Sequenase, Taq, and Vent can be usefully improved by appropriate changes in $\mathrm{pH}$, concentrations of $\mathrm{dNTP}$, and $\mathrm{Mg}^{2+}$ ion relative to conditions previously employed in PCR. It is probable that there are factors other than dNTP, $\mathrm{pH}$, and $\mathrm{Mg}^{2+}$ that are also important for their fidelity in which overall mutant fractions of less than $10 \%$ are required for 100 bp sequences amplified a million-fold. The conditions represented in the results of this study were limited to those that allowed efficient amplification of a specific template, HPRT exon 3 . It is probable that fidelity and efficiency are functions of the DNA sequence being amplified. The variations in the fidelity and efficiency of different lots of DNA polymerases is of practical importance in experimental procedure and should be noted. Thus, it is important to optimize the PCR conditions based on the DNA sequence of interest and the purpose of the study. The major improvement in the fidelity of Taq was achieved at very low amplification efficiency $(-36 \%)$ whereas Vent $(-70 \%)$ and Sequenase $(\sim 90 \%)$ consistently showed efficient amplification. Our results showed that Vent, a thermostable DNA polymerase, is as accurate in DNA synthesis as Sequenase and should be of use to researchers generating PCR products.

\section{ACKNOWLEDGMENTS}

This work was supported by grants from the U.S. Department of Energy (DE-FG02-86ER60448) and the National Institute of Environmental Health Sciences (P30-ES02109, 2P01-ES03926, 5P01-ES01640, and 5P42-ES04675).

\section{REFERENCES}

1. Saiki, R.K., S. Scharf, F. Faloona, K.B. Mullis, G.T. Horn, H.A. Erlich, and N. Arnheim. 1985. Enzymatic amplification of B-globin genomic sequences and restriction site analysis for diagnosis of sickle cell anemia. Science 230: 1350-1354.

2. Mullis, K.B. and F.A. Faloona. 1987. Specific synthesis of DN $\Lambda$ in vitro via a polymerase-catalysed chain reaction. Methods Enzymol. 155: 335-350.

3. Kleppe, K., E. Ohtsuka, R. Kleppe, I. Molineux, and H.G. Khorana. 1971. Studies on polynucleotides. XCVI. Repair replications of short synthetic DNA's as catalyzed by DNA polymerases. J. Mol. Biol. 56: 341-361.

4. Keohavong, P. and W.G. Thilly. 1989. Fidelity of DNA polymerases in DNA amplification. Proc. Natl. Acad. Sci. 86: 9253-9257.

5. Loeb, L.A. and T.A. Kunkel. 1982. Fidelity of DNA synthesis. Annu. Rev. Biochem. 52: 429-457.

6. Kunkel, T.A., L.A. Loeb, and M.F. Goodman. 1984. On the fidelity of DNA replication. J. Biol. Chem. 259: 1539-1545.

7. Eckert, K.A. and T.A. Kunkel. 1990. High fidelity DNA synthesis by the Thermus aquaticus DNA polymerase. Nucleic Acids Res. 18: 3739-3744.

8. Tindall, K.R. and T.A. Kunkel. 1988. Fidelity of DNA synthesis by the Thermus aquaticus DNA polymerase. Biochemistry 27: 6008-6013.

9. Eckert, K.A. and T.A. Kunkel. 1991. The fidelity of DNA polymerases used in the PCR. In Polymerase chain reaction: A practical approach (eds. M.J. McPherson, P. Quirke, and G.R. Taylor), pp. 227-246. IRL Press at Oxford University Press, Oxford (in press).

10. Scharf, S.J., G.T. Horn, and H.A. Erlich. 1986. Direct cloning and sequence analysis of enzymatically amplified genomic sequences. Science 233: 1076-1078.

11. Pääbo, S., D.M. Irwin, and A.C. Wilson. 1990. DNA damage promotes jumping between templates during enzymatic amplification. $J$. Biol. 
Chem. 265: 4718-4721.

12. Gyllensten, U. and H.A. Erlich. 1988. Generation of single stranded DNA by the polymerase chain reaction and its application to direct sequencing of the HLA DQ alpha locus. Proc. Natl. Acad. Sci. 85: 7652-7656.

13. Cariello, N.F., J.K. Scott, A.G. Kat, W.G. Thilly, and P. Keohavong. 1988. Resolution of a missense mutant in human genomic DNA by denaturing gradient gel electrophoresis and direct sequencing using in vitro DNA amplification: HPRT Munich. Am. I. Hum. Genet. 42: 726-734.

14. Keohavong, P., A.,G. Kat, N.F. Cariello, and W.G. Thilly. 1988. Laboratory methods: DNA amplification in vitro using T4 DNA polymerase. DNA 7: 63-70.

15. Vent ${ }^{\text {TM }}$ DNA polymerase technical bulletin from New England Biolabs. 1990 and 1991.

16. Goodman, M.F. 1988. DNA replication fidelity: Kinetics and thermodynamics. Mutat. Res, 200: 11-20.

17. Kunkel, T.A., R.D. Sabatino, and R.A Bambara. 1987.Exonucleolytic proofreading by calf thymus DNA polymerase delta. Proc. Natl. Acad. Sci. 84: 4865-4869.

18. Sirover, M.A., D.K. Dube, and L.A. Loeb. 1979. On the fidelity of DNA replication: Metal activation of Escherichia-Coli DNA polymerase. /. Biol. Chem. 254: 107-111.

19. Kunkel, T.A. and L.A. Loeb. 1979. On the fidelity of DNA replication: Effect of divalent metal ion activators and deoxyribonucleoside triphosphate pools on in vitro mutagenesis. J. Biol. Chem. 254: 5718-5725.

20. Weymouth, L.A. and L.A. Loeb. 1978. Mutagenesis during in vitro DNA synthesis. Proc. Natl. Acad. Sci. 75: 1924-1928.

21. Myers, R.M., N. Lumelsky, L.S. Lerman, and T. Maniatis. 1985. Detection of single base substitution in total genomic DNA. Nature 313: 495-498.

22. Huber, H.E., M. Russel, P. Model, and C.C. Richardson. 1986. Interaction of mutant thioredoxins of Escherichia coli with the gene 5 protein of phage T7. J. Biol. Chem. 261: 15006-15012.

23. Kunkel, T.A. 1988. Exonucleolytic proofreading. Cell 53: 837-840.

24. Kunkel, T.A. and A. Soni. 1988.
Exonucleolytic proofreading enhances the fidelity of DNA synthesis by chick embryo DNA polymerase- $\gamma$. J. Biol. Chem. 263: 4450-4459.

25. Ninio, J. 1975. Kinetic amplification of enzyme discrimination. Biochimie 57: $587-595$.

Received May 1, 1991; accepted in revised form July 2, 1991. 


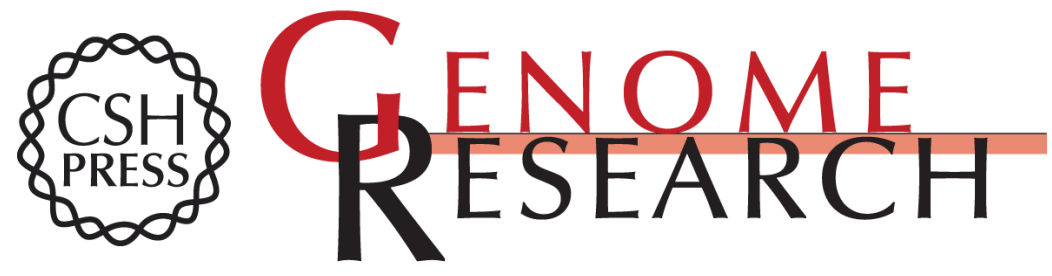

\section{Optimization of the polymerase chain reaction with regard to fidelity: modified T7, Taq, and vent DNA polymerases.}

L L Ling, P Keohavong, C Dias, et al.

Genome Res. 1991 1: 63-69

Access the most recent version at doi:10.1101/gr.1.1.63

References This article cites 23 articles, 12 of which can be accessed free at:

http://genome.cshlp.org/content/1/1/63.full.html\#ref-list-1

\section{License}

Email Alerting Receive free email alerts when new articles cite this article - sign up in the box at the Service top right corner of the article or click here.

\section{Affordable, Accurate Sequencing.}

To subscribe to Genome Research go to:

https://genome.cshlp.org/subscriptions 